\title{
Dynamics of plasma hepatitis B virus levels after highly active antiretroviral therapy in patients with HIV infection ${ }^{\text {is }}$
}

\author{
Chi-Tai Fang ${ }^{1}$, Pei-Jer Chen ${ }^{1,2,3}$, Mao-Yuan Chen ${ }^{1}$, Chien-Ching Hung ${ }^{1}$, Shan-Chwen Chang $^{1}$, \\ An-Lung Chang ${ }^{4}$, Ding-Shinn Chen ${ }^{1,2,3, *}$ \\ ${ }^{1}$ Department of Internal Medicine, National Taiwan University Hospital, Taipei, Taiwan \\ ${ }^{2}$ Hepatitis Research Center, National Taiwan University Hospital, Taipei, Taiwan \\ ${ }^{3}$ Graduate Institute of Clinical Medicine, National Taiwan University College of Medicine, 1 Jen-Ai Road, Taipei 100, Taiwan \\ ${ }^{4}$ Taipei Municipal Venereal Disease Control Institute, Taipei, Taiwan
}

Background/Aims: The optimal strategy to prescribe highly active antiretroviral therapy (HAART) in patients infected with both hepatitis B virus (HBV) and human immunodeficiency virus (HIV) remains unsettled. This study aimed to compare the HBV dynamics between HBeAg-positive and HBeAg-negative coinfected patients treated with lamivudine-containing HAART.

Methods: We retrospectively analyzed the serial changes of plasma HBV DNA levels in 24 HBsAg-positive HIVinfected patients who entered the HAART program. A polymerase chain reaction-based assay, capable of quantifying as few as $400 \mathrm{HBV}$ copies/ml, was used. The median follow-up time was 18 months.

Results: HAART containing lamivudine $300 \mathrm{mg} /$ day effectively suppressed plasma HBV-DNA to $10^{-3}-10^{-5}$-fold of the baseline levels, but a multi-phasic decay of HBV DNA was observed. The later phases became flat, as a persistent residual HBV viremia, in eight of the studied $10 \mathrm{HBeAg}$-positive patients; in contrast, residual HBV viremia was not observed in the $10 \mathrm{HBeAg}$-negative patients studied (8/10 vs. 0/10, $P=0.0007$, Fisher's exact test). HAART without lamivudine did not suppress plasma HBV DNA levels in the remaining four patients.

Conclusions: HAART containing lamivudine $300 \mathrm{mg} /$ day effectively suppress $\mathrm{HBV}$ replication in HBeAg-negative HIV/HBV-coinfected patients. Nevertheless, residual HBV replication persisted in most HBeAg-positive coinfected patients.

(C) 2003 European Association for the Study of the Liver. Published by Elsevier B.V. All rights reserved.

Keywords: Hepatitis B; Human immunodeficiency virus infection; Lamivudine; Highly active antiretroviral therapy

\section{Introduction}

Chronic hepatitis B has become an increasingly important cause of morbidity and mortality in human immunodeficiency virus (HIV)-infected patients [1-3] after their prolonged survival is made possible by advances in highly active antiretroviral therapy (HAART) [4-6]. Due to shared

Received 24 June 2003; received in revised form 4 August 2003; accepted 11 August 2003

The authors of the study have declared that they have no relationship, nor did they receive funding from the manufacturers of the drug(s) involved in the study.

* Corresponding author: Dean, National Taiwan University College of Medicine, 1 Jen-Ai Road, Taipei 100, Taiwan. Tel.: +886-2-2312-

3456x8000; fax: +886-2-2331-7624 or 2322-4793.

E-mail address: dschen@ha.mc.ntu.edu.tw (D.-S. Chen). transmission routes and impaired host immune response, chronic hepatitis B virus (HBV) infection was common in HIV-infected patients [7,8]. In addition to hepatitis, chronic HBV infection can further cause liver cirrhosis and hepatocellular carcinoma, especially in hepatitis B e antigen (HBeAg)-positive patients [9-11]. Compared with patients infected with HBV alone, patients infected with both HIV and HBV had higher levels of HBV replication, higher risk for cirrhosis and increased risk of liver-related mortality $[12,13]$. HIV/HBV-coinfected patients with chronic active hepatitis $\mathrm{B}$ should be considered candidates to receive antiviral therapy against HBV, such as lamivudine [14-16], adefovir $[17,18]$, tenofovir $[19,20]$ or interferon- $\alpha[21,22]$. Nevertheless, the optimal management strategy is less clear for the majority of HIV/HBV-coinfected patients who did not have clinical hepatitis when their HIV infection was 
diagnosed. When prescribing HAART for these patients, it is not known whether lamivudine, which is also an antiretroviral agent active against HIV [15], should be included in the HAART regimen or, on the contrary, should not be used until active hepatitis B developed.

This study aimed to characterize the dynamics of HBV after the start of HAART in patients infected with both HIV and HBV. HAART regimens with or without lamivudine, and patients with or without $\mathrm{HBeAg}$ in their serum, were compared. To analyze the HBV dynamics below the detection limit of conventional molecular hybridization assay, a quantitative polymerase chain reaction (PCR)based assay [23,24], capable of quantifying as few as 400 copies/ml, was used.

\section{Patients and methods}

\subsection{Patients}

Studied patients belong to a cohort of 579 consecutive HIV-infected patients entered into the HAART program at National Taiwan University Hospital (NTUH) (Taipei, Taiwan) and Taipei Municipal Venereal Disease Control Institute (TMVDC) (Taipei, Taiwan) since 1997. NTUH and TMVDC, cooperate closely to provide HIV-infected patients integrative medical service, have the largest cohort of HIV-infected patients in Taiwan. Baseline assessments before the start of HAART included Western blot confirmation of HIV-1 infection, clinical evaluation, serum biochemical profile, peripheral blood CD4 + lymphocyte count and plasma HIV RNA. The timing for initiating HAART and the regimens were based on guidelines recommended in the United States [25]. After the start of HAART, the patients were monitored monthly in outpatient clinics. Plasma samples collected at baseline, 1 month after the start of HAART and every 3 months thereafter were stored at $-80{ }^{\circ} \mathrm{C}$ until use. Informed consent was obtained from each patient included in the study. The study protocol conforms to the ethical guidelines of the 1975 Declaration of Helsinki as reflected in a priori approval by our institution's human research committee.

\subsection{Study procedure}

The HBV and hepatitis C virus (HCV) serological status of the patients were determined retrospectively using baseline plasma samples. Patients were included in the study if they fulfilled the following criteria: (1) were HBsAg-seropositive but negative for anti-HCV antibody; (2) had plasma samples at baseline, 1 month after the start of HAART and every 3 months thereafter for at least three times. Demographic and clinical information, presence of acquired immunodeficiency syndrome (AIDS) [26], biochemical data, CD4 + lymphocyte counts and HIV RNA levels were retrospectively obtained from the medical records. Patients who had questionable adherence to the HAART regimens, as evidenced by missing scheduled follow-ups or failure to have a sustained rise in peripheral blood CD4 + lymphocyte counts while receiving HAART, were excluded.

\subsection{Laboratory assays}

The serological markers for $\mathrm{HBV}$ and $\mathrm{HCV}$ were determined by commercial immunoassays (Abbott Diagnostics, North Chicago, IL, USA). Plasma HBV-DNA level was quantified by Amplicor HBV Monitor (Roche Diagnostics, Basel, Switzerland). This test is based on quantitative PCR [23], and the assay is accurate over the range from $4 \times 10^{2}$ to $4 \times 10^{7} \mathrm{HBV}$ DNA copies/ml [24]. When the HBV DNA levels in plasma samples exceeded $4 \times 10^{7}$ copies $/ \mathrm{ml}$, the quantitation was repeated after appropriate dilution with normal human plasma.

\subsection{Statistical analysis}

Means and proportions were compared by using Student's $t$-test and Fisher's exact test, respectively. The statistical software used for computation was S-PLUS 2000 for Windows (MathSoft Inc., MA, USA). Two-tailed $P$ values of less than 0.05 were considered to be statistically significant.

\section{Results}

\subsection{Patient characteristics}

Of the $579 \mathrm{HIV}$-infected patients, 97 were retrospectively identified to be HBsAg-seropositive and 53 of them met the inclusion criteria (44 patients were excluded: 29 had questionable adherence to HAART; nine had insufficient plasma samples; four lost follow-up; and two had positive anti-HCV antibody). Among these 53 patients, 49 (13 HBeAg-positive and $36 \mathrm{HBeAg}$-negative) received HAART regimens containing lamivudine $150 \mathrm{mg}$ twice daily and four (one $\mathrm{HBeAg}$-positive and three $\mathrm{HBeAg}$ negative) received HAART regimens without lamivudine. Only one of these 53 patients have active hepatitis (defined as elevated serum aspartate aminotransferase and alanine aminotransferase 3-fold higher than the upper limit of the reference values) when HAART was started. Ten HBeAgpositive and $10 \mathrm{HBeAg}$-negative patients were randomly selected out of the 49 patients received lamivudinecontaining HAART regimens, along with the four patients on HAART regimens without lamivudine, for further study. The demographic features, baseline CD4 + lymphocyte count and HBeAg status, presence of AIDS when HAART was started, HAART regimens and the follow-up duration of these 24 patients are listed in Table 1.

\subsection{HAART regimens without lamivudine}

Patients 1-4 received HAART regimens without lamivudine for 287-719 days (9-24 months) (Table 1). Patients 1,2 and 4 had sustained increases in CD $4+$ counts. The CD $4+$ count was $670 / \mu$ l in Patient 3 initially, and remained in the normal range $(500-1500 / \mu 1)$ throughout the study period. All of them also had plasma HIV RNA levels suppressed to undetectable levels $(<400$ copies $/ \mathrm{ml})$ after the start of HAART. The plasma HIV RNA in Patients 2-4 remained undetectable throughout the follow-up period, while low-level HIV viremia 757 copies/ml reemerged on day 288 in Patient 1 and gradually increased to $5.3 \times 10^{3}$ copies $/ \mathrm{ml}$ at the last follow-up visit (day 533).

The serial plasma HBV DNA levels after the start of HAART in Patients $1-4$ are shown in Fig. 1. Despite the increase in CD4 counts and the suppression of HIV viremia, HAART without lamivudine did not suppress plasma HBV DNA in these four patients (Fig. 1). None of these four patients experienced flare-up of clinical hepatitis during the study period. 
Table 1

Baseline characteristics, highly active antiretroviral therapy regimens, and follow-up durations of the 24 patients studied

\begin{tabular}{lllll}
\hline Patient no. & Age (years)/Sex & $\begin{array}{l}\text { Initial serum } \\
\mathrm{HBeAg}\end{array}$ & $\begin{array}{l}\text { Initial CD4 }+ \\
\text { count }(/ \mu \mathrm{l})\end{array}$ & $\begin{array}{l}\text { AIDS } \\
\text { Regimens of highly } \\
\text { active antiretroviral } \\
\text { therapy (HAART) }\end{array}$
\end{tabular}

HAART regimens

without lamivudine

1
2
3
4

$\begin{array}{lll}28 / \mathrm{M} & - & \\ 48 / \mathrm{M} & - & 257 \\ 25 / \mathrm{M} & + & 67 \\ 38 / \mathrm{M} & - & 216\end{array}$

Yes
No
No
Yes

$\begin{array}{ll}\mathrm{AZT}+\mathrm{ddC}+\mathrm{RTV} & 533 \\ \mathrm{AZT}+\mathrm{ddC}+\mathrm{RTV} & 503 \\ \mathrm{AZT}+\mathrm{ddC}+\mathrm{SQV} & 719 \\ \mathrm{AZT}+\mathrm{ddI}+\mathrm{IDV} & 287 \\ \text { (days } 1-42), & \end{array}$

$\mathrm{d} 4 \mathrm{~T}+\mathrm{ddI}+\mathrm{RTV}+\mathrm{SQV}$

(days 42-287)

HAART regimens with lamivudine $300 \mathrm{mg} /$ day: HBeAg-positive group 5

136

Yes

$3 \mathrm{TC}+\mathrm{AZT}+\mathrm{RTV}$

(days 1-293),

$3 \mathrm{TC}+\mathrm{AZT}+\mathrm{IDV}$

(days 293-546)

6
8

$38 / \mathrm{M}$

$34 / \mathrm{M}$

$35 / \mathrm{M}$

$30 / \mathrm{M}$

Yes

$3 \mathrm{TC}+\mathrm{AZT}+\mathrm{IDV}$

$3 \mathrm{TC}+\mathrm{AZT}+\mathrm{IDV}$

$3 \mathrm{TC}+\mathrm{d} 4 \mathrm{~T}+\mathrm{IDV}$

$3 \mathrm{TC}+\mathrm{AZT}+\mathrm{RTV}$

(days 1-28),

$3 \mathrm{TC}+\mathrm{AZT}+\mathrm{SQV}$

(days 28-721)

$+\quad 377$

$3 \mathrm{TC}+\mathrm{d} 4 \mathrm{~T}+\mathrm{IDV}$

$3 \mathrm{TC}+\mathrm{AZT}+\mathrm{SQV}$

$3 \mathrm{TC}+\mathrm{ddI}+\mathrm{IDV}$

$3 \mathrm{TC}+\mathrm{AZT}+\mathrm{RTV}$

(days 1-35),

$3 \mathrm{TC}+\mathrm{d} 4 \mathrm{~T}+\mathrm{SQV}$

(days 35-658)

HAART regimens with lamivudine $300 \mathrm{mg} /$ day: HBeAg-negative group 15

$3 \mathrm{TC}+\mathrm{AZT}+\mathrm{RTV}$

$3 \mathrm{TC}+\mathrm{AZT}+\mathrm{SQV}$

(days 1-84),

$3 \mathrm{TC}+\mathrm{d} 4 \mathrm{~T}+\mathrm{IDV}$ (days 84-566)

\begin{tabular}{|c|c|c|c|c|c|}
\hline 19 & $45 / \mathrm{M}$ & - & 78 & Yes & $3 \mathrm{TC}+\mathrm{ddC}+\mathrm{IDV}$ \\
\hline 20 & 29/M & - & 21 & Yes & $3 \mathrm{TC}+\mathrm{AZT}+\mathrm{RTV}$ \\
\hline 21 & $47 / \mathrm{M}$ & - & 76 & Yes & $3 \mathrm{TC}+\mathrm{AZT}+\mathrm{IDV}$ \\
\hline 22 & $35 / \mathrm{M}$ & - & 19 & Yes & $3 \mathrm{TC}+\mathrm{ddC}+\mathrm{IDV}$ \\
\hline 23 & $33 / \mathrm{M}$ & - & 216 & No & $\begin{array}{l}3 \mathrm{TC}+\mathrm{AZT}+\mathrm{RTV} \\
\text { (days } 1-57), \\
3 \mathrm{TC}+\mathrm{AZT}+\mathrm{IDV} \\
(\text { days } 57-176), \\
3 \mathrm{TC}+\mathrm{d} 4 \mathrm{~T}+\mathrm{IDV} \\
\text { (days } 176-407)\end{array}$ \\
\hline 24 & $32 / \mathrm{M}$ & - & 220 & No & $\begin{array}{l}3 \mathrm{TC}+\mathrm{AZT}+\mathrm{RTV} \\
(\text { days } 1-42), \\
3 \mathrm{TC}+\mathrm{AZT}+\mathrm{IDV} \\
(\text { days } 42-396)\end{array}$ \\
\hline
\end{tabular}

3TC, lamivudine, AZT, zidovudine; d4T, stavudine; ddC, deoxycytidine; ddI, didanosine; RTV, ritonavir; IDV, indinavir; SQV, saquinavir. 

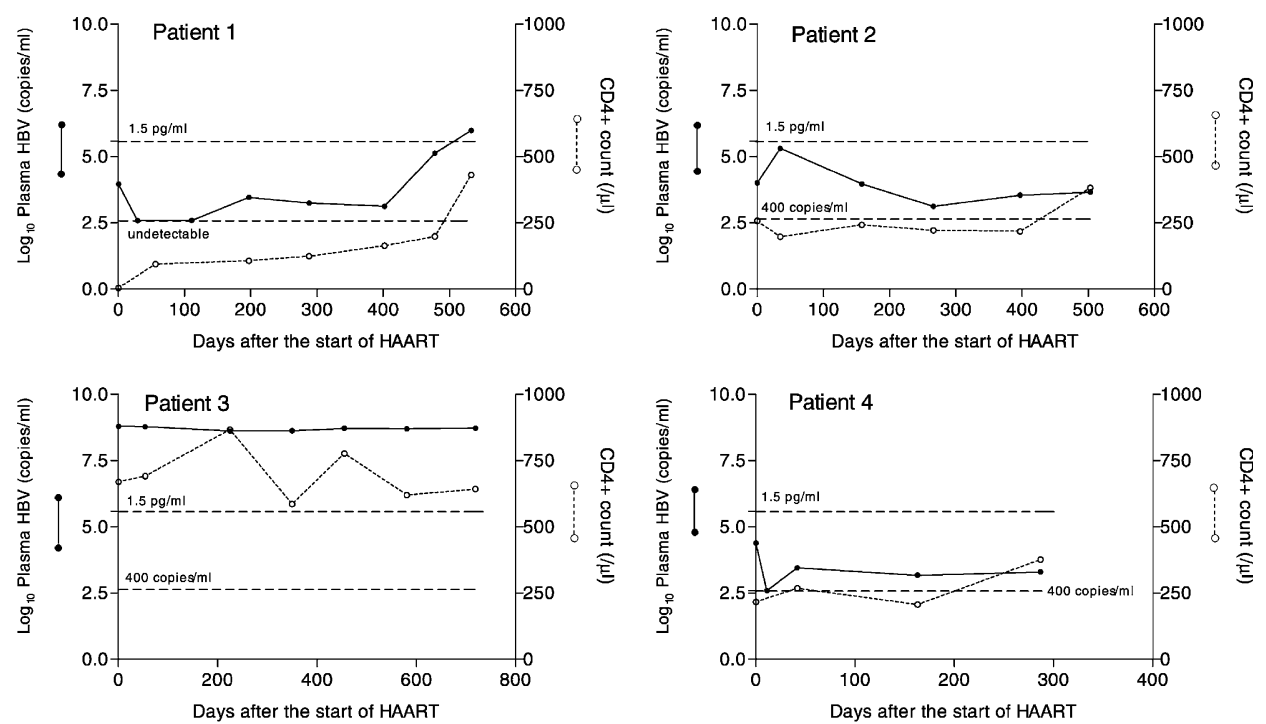

Fig. 1. Serial changes of plasma HBV DNA levels and CD4 counts after the start of highly active antiretroviral therapy regimens without lamivudine in four HIV/HBV-coinfected patients (Patients 1-4). Patient 3 was HBeAg-positive while Patients 1, 2, and 4 were HBeAg-negative.

\subsection{HAART regimens with lamivudine $300 \mathrm{mg} /$ day: HBeAg-positive patients}

Patients 5-14 received HAART regimens with lamivudine $150 \mathrm{mg}$ b.i.d. as a component for 435-820 days (14-27 months) (Table 1). All of them had sustained increases in CD4 + counts. Except for Patients 5 and 7, all of them also had plasma HIV RNA suppressed to undetectable levels $(<400$ copies $/ \mathrm{ml})$ after the start of HAART and throughout the follow-up period. In Patient 5, plasma HIV RNA was suppressed to undetectable level after the start of HAART, but HIV viremia $1.9 \times 10^{4}$ copies $/ \mathrm{ml}$ re-emerged on day 179 and gradually increased to $6.2 \times 10^{4}$ copies/ml at the last follow-up (day 546). In Patient 7, plasma HIV RNA level was suppressed to the lowest level of 1040 copies/ml on day 30 of HAART, and then gradually increased to $4.1 \times 10^{4}$ at the last follow-up visit (day 435).

Serial plasma HBV DNA levels after the start of HAART in Patients 5-14 are shown in Fig. 2. All ten patients had plasma HBV DNA suppressed to $10^{-3}-10^{-5}$-fold of the baseline levels (median: $-4.4 \log _{10}$ copies/ml). The suppression sustained at the last follow-up visits. Nevertheless, the HBV DNA decay curves showed a complex multi-phasic pattern with significant individual variation.
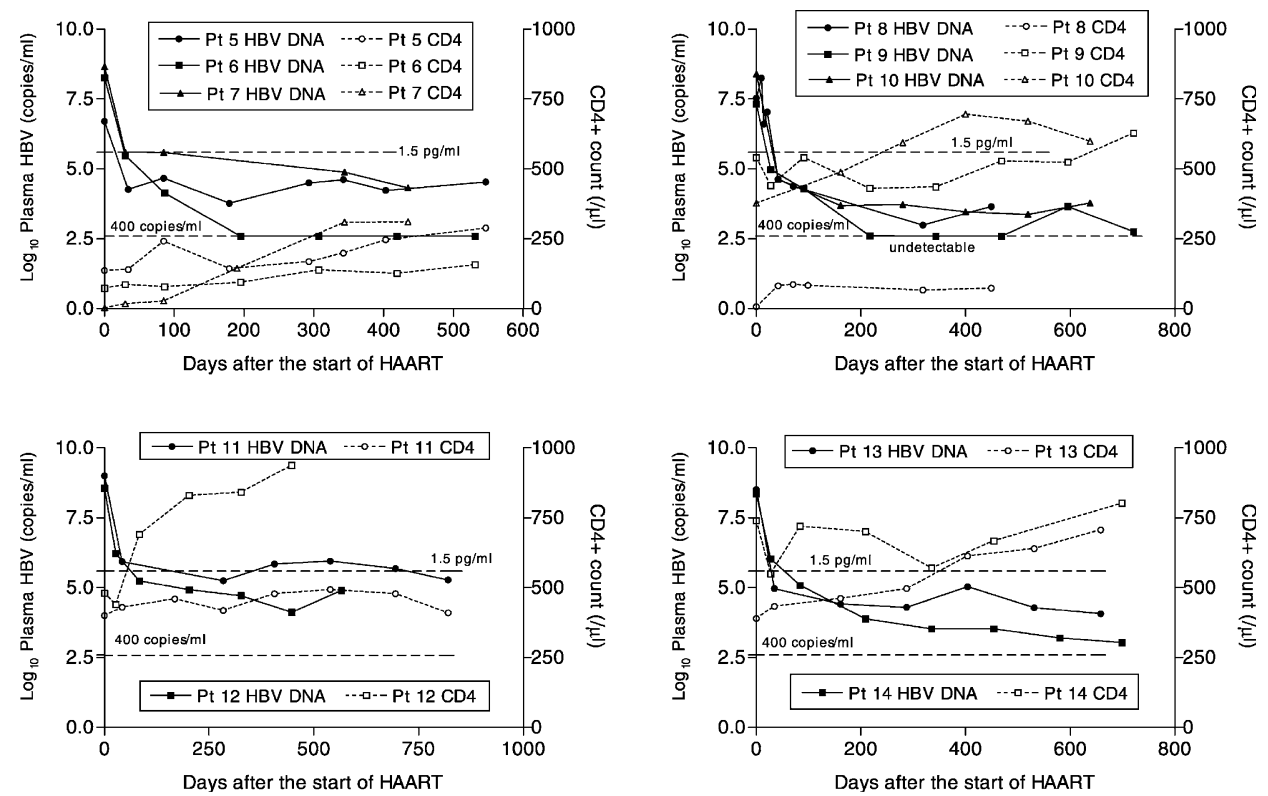

Fig. 2. Multi-phasic plasma HBV DNA decay curves after the start of highly active antiretroviral therapy regimens with lamivudine 300 mg/day as a component in 10 HBeAg-positive HIV/HBV-coinfected patients (Patients 5-14). CD4 counts are also shown. 
An initial rapid decline of plasma HBV DNA was followed by the slower second phase decay, and then the even slower later phases (Fig. 2). In Patients 6 and 9, the plasma HBV DNA finally became undetectable $(<400$ copies/ml); while in the remaining eight patients, the later phases became flat, as a persistent residual HBV viremia, at the last follow-up (Fig. 2). This persistent residual HBV viremia, ranging from $10^{3}$ to $10^{5}$ copies $/ \mathrm{ml}$, would not be detectable by the conventional molecular hybridization assay (with a lower detection limit of $1.5 \mathrm{pg} / \mathrm{ml}$ or $4 \times 10^{5}$ copies $/ \mathrm{ml}$ ). There was no apparent correlation between this residual viremia and CD4 counts of the patients. We tested the last plasma samples from Patients 5 and 7 to see whether this residual HBV viremia was caused by lamivudine-resistant HBV mutants. However, no mutation in the YMDD motif of the HBV DNA polymerase could be identified. None of these ten patients experienced flare-up of clinical hepatitis during the period studied. At the last follow-up visit, nine of these ten patients (except for Patient 9) remained $\mathrm{HBeAg}$ seropositive.

\subsection{HAART regimens with lamivudine $300 \mathrm{mg} /$ day: HBeAg-negative patients}

Patients 15-24 received HAART regimens with lamivudine $150 \mathrm{mg}$ b.i.d. as a component for 396-566 days (13-19 months) (Table 1). All of them had a sustained rise in CD4 + count. Except for Patient 18, all of them also had plasma HIV RNA suppressed to undetectable levels $(<400$ copies $/ \mathrm{ml}$ ) after the start of HAART and throughout the follow-up period. Patient 18 had his lowest plasma HIV RNA level of $4.6 \times 10^{4}$ copies/ml on day 84 of HAART, which then gradually increased to $6.5 \times 10^{4}$ at the last follow-up (day 566).

The serial plasma HBV DNA levels after the start of HAART in Patients 15-24 are shown in Fig. 3. These HBeAg-negative patients had an initial HBV DNA level significantly lower than that of the $\mathrm{HBeAg}$-positive patients (Fig. 2 vs. Fig. 3: $\log _{10}$ copies/ml $8.13 \pm 0.71$ vs. $4.90 \pm 2.03, P=0.0006$, Student's $t$-test). Nevertheless, the multi-phasic HBV DNA decay pattern still can be identified in Patients 16, 18, 20, and 22 (Fig. 3). At the last follow-up visit, sustained suppression of plasma HBV DNA $(<400$ copies $/ \mathrm{ml})$ was achieved in all ten patients, without detectable residual HBV viremia. The observed difference, in terms of $\mathrm{HBV}$ viral load at the last follow-up, between $\mathrm{HBeAg-positive} \mathrm{and} \mathrm{HBeAg}$-negative patients was statistically highly significant (Fig. 2 vs. Fig. 3: $\log _{10}$ copies $/ \mathrm{ml}$ $3.89 \pm 0.90$ vs. $<2.60, P=0.001$, Student's $t$-test). None of these ten patients experienced flare-up of clinical hepatitis during the study period.

Three patients (Patients 17, 21 and 23) had very low levels of baseline plasma HBV DNA (558 copies/ml, 1650 copies/ml, and $<400$ copies/ml, respectively) (Fig. 3). After prolonged HAART with lamivudine $300 \mathrm{mg} /$ day, none of these three patients lost HBsAg at the last followups (day 514, day 511 and day 407, respectively).

\section{Discussion}

This study shows that HAART regimens containing lamivudine $300 \mathrm{mg} /$ day can suppress $\mathrm{HBV}$ viremia to $10^{-3}-10^{-5}$-fold of baseline levels in patients infected by
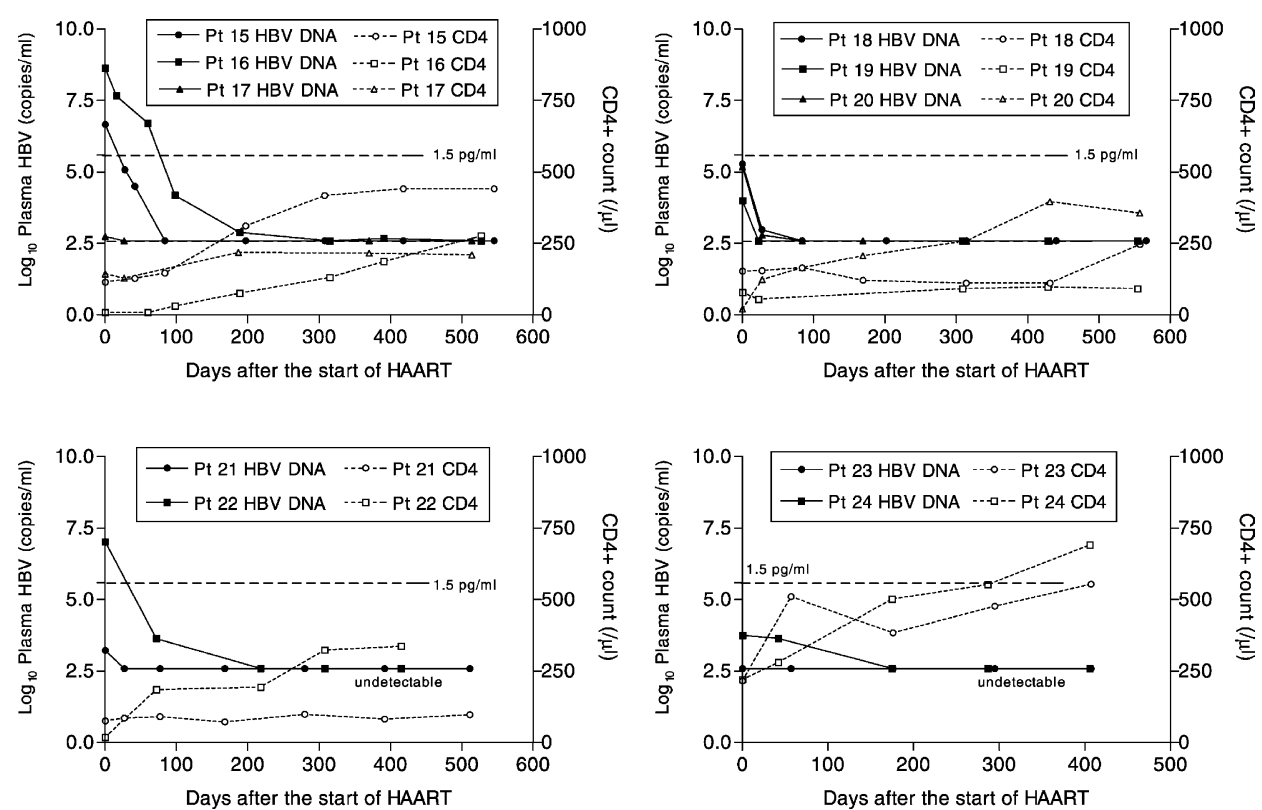

Fig. 3. Plasma HBV DNA decay curve after the start of highly active antiretroviral therapy regimens with lamivudine $300 \mathrm{mg} /$ day as a component in 10 HBeAg-negative HIV/HBV-coinfected patients (Patients 15-24). CD4 counts are also shown. 
both HIV and HBV. The decay curve of HBV DNA followed a complex multi-phasic pattern similar to that observed in non-HIV patients [27,28]. The later phases became flat, as a persistent residual HBV viremia, in eight of the studied $10 \mathrm{HBeAg}$-positive patients; in contrast, residual $\mathrm{HBV}$ viremia was not observed in the ten $\mathrm{HBeAg-}$ negative patients studied $(8 / 10$ versus $0 / 10, P=0.0007$, Fisher's exact test). This finding indicates that HAART containing lamivudine $300 \mathrm{mg}$ /day can effectively suppress $\mathrm{HBV}$ replication in $\mathrm{HBeAg}$-negative $\mathrm{HIV} / \mathrm{HBV}$-coinfected patients, but more potent antiviral regimens against HBV are probably required to effectively suppress HBV replication in $\mathrm{HBeAg}$-positive coinfected patients.

In addition to the direct antiviral effect of lamivudine, HAART will increase CD4 counts in coinfected patients and this should potentially affect the viral kinetics, as demonstrated by the two case reports about clearance of HBV viremia after immunorestoration after HAART without lamivudine [29,30]. We did not observe this phenomenon in Patients 1-4, however. An important difference between Taiwanian patients and Western patients is the timing of acquiring HBV and HIV. The majority of Taiwanian patients had acquired HBV through perinatal transmission soon after birth or infections in early childhood [9-11] and became HBsAg carriers long before they contracted HIV infection. The early HBV infection makes Taiwanian HBsAg carriers immunotolerant to $\mathrm{HBV}$, and thus it is unlikely that HAART-induced immunorestoration can result in clearance of $\mathrm{HBV}$ in such patients. This is in contrast to Western patients who acquired both viruses through horizontal transmission approximately at the same time. HIV coinfection increases the rate of chronic HBsAg carriage after acute infection in Western patients through its immunosuppressive effect [8], thus some of them will be able to clear HBV viremia after HAART-induced immunorestoration without the use of lamivudine [29,30].

It has been reported that all of the HIV/HBV-coinfected patients who received lamivudine as a part of HAART and subsequently developed HBV resistance to lamivudine were initially $\mathrm{HBeAg}$-positive [31]. The presence of persistent residual $\mathrm{HBV}$ viremia in $\mathrm{HBe} \mathrm{Ag}$-positive patients on lamivudine $300 \mathrm{mg} /$ day therapy, but not in $\mathrm{HBeAg}$-negative patients, explains this previously observed difference in risk of development of lamivudine resistance. Emergence of lamivudine-resistant mutants will be an inevitable result if HBV continues to replicate in the presence of lamivudine. Although we did not detect the YMDD mutation in Patients 5 and 7 at the end of this study, those HBeAg-positive patients with persistent residual HBV viremia on lamivudine therapy have a definite risk in developing HBV resistance to lamivudine in the following years.

Previous studies in viral dynamics found that the most plausible explanation of the biphasic or multi-phasic clearance kinetics is that the antiviral given does not completely inhibit residual HBV production from the already infected hepatocytes, and the second and the later phases reflect the slow decay of these cells [32,33]. The individual variations in HBV decay kinetics observed in this study are probably caused by variations in both number and half-life of the infected hepatocytes in different patients. The existence of a flat phase or persistent residual viremia indicates that the responsible $\mathrm{HBV}$-infected cells have a very long, almost indefinite, half-life. These cells cannot be the usual hepatocytes, which are not immortal. In addition to the usual hepatocytes, HBV can also infect oval cells of the liver [34], which are less differentiated and behave like stem cells, capable of proliferating in response to hepatic injury [35]. We therefore hypothesize that the infected oval cells, with an almost indefinite half-life, may be the source of this nearly constant persistent residual $\mathrm{HBV}$ viremia. If this is indeed the case, the presence of this compartment of extremely long-lived infected cells will make eradication of HBV almost impossible even though potent combination antiviral regimens are used, similar to the situation in HAART against HIV [33].

Since HAART regimens containing lamivudine 300 $\mathrm{mg}$ /day, as a monotherapy for hepatitis B, cannot effectively suppress $\mathrm{HBV}$ replication in most $\mathrm{HBeAg}$-positive HIV/HBV-coinfected patients, prescribing such regimens when they do not have active hepatitis B will put them at significant risk of subsequent development of the HBV resistance to lamivudine. This will limit the choice of antiHBV agents for these patients if someday they develop active hepatitis and require specific antiviral therapy against HBV. Thus, serum HBeAg status should be routinely checked before prescribing HAART for HIV/HBV-coinfected patients even though they do not have active hepatitis at that time. For HBeAg-positive coinfected patients without clinical hepatitis, lamivudine should be avoided in the HAART regimens if possible. Thus, lamivudine can be reserved for future use when needed. The guidelines remain to be seen for HBeAg-negative coinfected patients with active HBV replication but without clinical hepatitis. Our results suggested that such precaution would probably not be necessary because lamivudine $300 \mathrm{mg} /$ day alone can effectively suppress HBV replication to undetectable levels in HBeAg-negative coinfected patients (Fig. 3).

Because HAART regimens without lamivudine did not have direct suppressive effect on HBV replication, HIV/HBV-coinfected patients received such regimens needed be closely monitored after the start of HAART. Flare-up of clinical hepatitis $\mathrm{B}$, either due to the nature course or secondary to the effect of the HAART-induced immunorestoration, is a major concern. None of the four patients received HAART regimens without lamivudine in our study developed this event, but it will certainly occur in some patients. In case of severe clinical flare-up, lamivudine or other anti-HBV regimens should be promptly given to minimize liver damage.

For HIV/HBV-coinfected patients with active chronic hepatitis $\mathrm{B}$, treatment with interferon- $\alpha$, lamivudine, adefovir or tenofovir should be considered [36]. Compared 
with non-HIV patients, interferon therapy had a significantly lower response rate in HIV-positive patients [21,22]. Lamivudine is associated with a high rate $(20-25 \%$ patients per year) of emergence of lamivudine-resistant HBV mutant in such patients $[31,37,38]$. The newly developed adefovir and tenofovir are promising agents inhibiting both HBV and HIV replication $[17,18,39]$. The currently approved dosage (10 mg/day) of adefovir, nevertheless, is suboptimal for inhibiting HIV [18]. Tenofovir inhibits both HIV and HBV at the approved dosage (300 mg/day) and can be used as a component of HAART against HIV to simplify the regimen in coinfected patients [20]. Further viral dynamic and clinical studies would be required to determine the best agent or combination in the treatment of chronic active hepatitis B in HIV/HBV-coinfected patients [36].

The impact of prolonged anti-HBV antiviral therapy on $\mathrm{HBV}$ status in HBsAg carrier with extremely low HBV replication is unknown, because such cases will not be the target of the anti-HBV antiviral therapy at present time. In this study, we had the opportunity to observe three coinfected patients with very low baseline HBV DNA levels. HBsAg remained detectable in all three patients after prolonged HAART with lamivudine $300 \mathrm{mg}$ /day for an average of 16 months. Perhaps the surface antigen gene has integrated to the host genome [40], and thus no longer can be affected by the antiviral therapy.

In conclusion, HAART containing lamivudine 300 $\mathrm{mg}$ /day effectively suppressed HBV replication in the HBeAg-negative coinfected patients. However, most HBeAg-positive coinfected patients still had ongoing residual $\mathrm{HBV}$ replication, and thus the regimen will put them at increased risk of subsequent development of HBV resistance to lamivudine. For $\mathrm{HBeAg}$-positive coinfected patients without clinical hepatitis, lamivudine should be avoided in the HAART regimens if possible.

\section{Acknowledgements}

This study was supported by grants DOH-88-DC-1029 and DOH-89-DC-1008 from the Department of Health, Executive Yuan, Taiwan. We would like to thank Dr. ShouChien Chen, Dr. Shiow-Ing Wu, and the Taipei Municipal Venereal Disease Control Institute for allowing us to recruit their patients for participation in this study. We also thank Miss Jia-Bao Pan and Miss Wen-Li Chen for their help in the laboratory work. The authors of the study have declared that they have no relationship, nor did they receive funding from the manufacturers of the drugs involved in the study.

\section{References}

[1] Martin-Carbonero L, Soriano V, Valencia E, Garcia-Samaniego J, Lopez M, Gonzalez-Lahoz J. Increasing impact of chronic viral hepatitis on hospital admissions and mortality among HIV-infected patients. AIDS Res Hum Retroviruses 2001;17:1467-1471.

[2] Puoti M, Spinetti A, Ghezzi A, Donato F, Zaltron S, Putzolu V, et al. Mortality for liver disease in patients with HIV infection: a cohort study. J Acquir Immune Defic Syndr 2000;24:211-217.

[3] Bica I, McGovern B, Dhar R, Stone D, McGowan K, Scheib R, Snydman DR. Increasing mortality due to end-stage liver disease in patients with human immunodeficiency virus infection. Clin Infect Dis 2001;32:492-497.

[4] Palella FJ, Delaney KM, Moorman AC, Loveless MO, Fuhrer J, Satten GA, et al. Declining morbidity and mortality among patients with advanced human immunodeficiency virus infection. N Engl J Med 1998;338:853-860.

[5] Mocroft A, Vella S, Benfield TL, Chiesi A, Miller V, Gargalianos P, et al. Changing patterns of mortality across Europe in patients infected with HIV-1. Lancet 1998;352:1725-1730.

[6] Moore RD, Chaisson RE. Natural history of HIV infection in the era of combination antiretroviral therapy. AIDS 1999;13:1933-1942.

[7] Rustgi VK, Hoofnagle JH, Gerin JL, Gelmann EP, Reichert CM, Cooper JN, Macher AM. Hepatitis B virus infection in the acquired immunodeficiency syndrome. Ann Intern Med 1984;101:795-797.

[8] Hadler SC, Judson FN, O’Malley PM, Altman NL, Penley K, Buchbinder $\mathrm{S}$, et al. Outcome of hepatitis $\mathrm{B}$ virus infection in homosexual men and its relation to prior human immunodeficiency virus infection. J Infect Dis 1991;163:454-459.

[9] Chen DS. From hepatitis to hepatoma: Lessons from type B viral hepatitis. Science 1993;262:369-370.

[10] Liaw YF, Tai DI, Chu CM, Chen TJ. The development of cirrhosis in patients with chronic type B hepatitis: a prospective study. Hepatology 1988;8:493-496.

[11] Yang HI, Lu SN, Liaw YF, You SL, Sun CA, Wang LY, et al. Hepatitis B e antigen and the risk of hepatocellular carcinoma. N Engl J Med 2002;347:168-174.

[12] Colin JF, Cazals-Hatem D, Loriot MA, Martinot-Peignoux M, Pham $\mathrm{BN}$, Auperin A, et al. Influence of human immunodeficiency virus infection on chronic hepatitis B in homosexual men. Hepatology 1999;29:1306-1310.

[13] Thio CL, Seaberg EC, Skolasky Jr R, Phair J, Visscher B, Munoz A, et al. HIV-1, hepatitis B virus, and risk of liver-related mortality in the Multicenter Cohort Study (MACS). Lancet 2002;360:1921-1926.

[14] Benhamou Y, Katlama C, Lunel F, Coutellier A, Dohin E, Hamm N, et al. Effects of lamivudine on replication of hepatitis B virus in HIVinfected men. Ann Intern Med 1996;125:705-712.

[15] Dore GJ, Cooper DA, Barret C, Goh LE, Thakrar B, Atkins M. Dual efficacy of lamivudine treatment in human immunodeficiency virus/ hepatitis B-coinfected persons in a randomized, controlled study (CAESAR). J Infect Dis 1999;180:607-608.

[16] Hoff J, Bani-Sadr F, Gassin M, Raffi F. Evaluation of chronic hepatitis $\mathrm{B}$ virus (HBV) infection in coinfected patients receiving lamivudine as a component of anti-human immunodeficiency virus regimens. Clin Infect Dis 2001;32:963-969.

[17] Benhamou Y, Bochet M, Thibault V, Calvez V, Fievet MH, Vig P, et al. Safety and efficacy of adefovir dipivoxil in patients co-infected with HIV-1 and lamivudine-resistant hepatitis B virus: an open-label pilot study. Lancet 2001;358:718-723.

[18] Delaugerre C, Marcelin AG, Thibault V, Peytavin G, Bombled T, Bochet MV, et al. Human immunodeficiency virus (HIV) Type 1 reverse transcriptase resistance mutations in hepatitis B virus (HBV)HIV-coinfected patients treated for HBV chronic infection once daily with 10 milligrams of adefovir dipivoxil combined with lamivudine. Antimicrob Agents Chemother 2002;46:1586-1588.

[19] Nelson M, Portsmouth S, Stebbing J, Atkins M, Barr A, Matthews G, et al. An open-label study of tenofovir in HIV-1 and Hepatitis B virus co-infected individuals. AIDS 2003;17:F7-F10.

[20] Ristig MB, Crippin J, Aberg JA, Powderly WG, Lisker-Melman M, Kessels L, et al. Tenofovir disoproxil fumarate therapy for chronic hepatitis B in human immunodeficiency virus/hepatitis B 
virus-coinfected individuals for whom interferon-alpha and lamivudine therapy have failed. J Infect Dis 2002;186:1844-1847.

[21] Wong DK, Yim C, Naylor CD, Chen E, Sherman M, Vas S, et al. Interferon alpha treatment of chronic hepatitis $\mathrm{B}$ : randomized trial in a predominantly homosexual male population. Gastroenterology 1995; 108:165-171.

[22] Di Martino V, Thevenot T, Colin JF, Boyer N, Martinot M, Degos F, et al. Influence of HIV infection on the response to interferon therapy and the long-term outcome of chronic hepatitis B. Gastroenterology 2002; $123: 1812-1822$.

[23] Gerken G, Gomes J, Lampertico P, Colombo M, Rothaar T, Trippler $\mathrm{M}$, et al. Clinical evaluation and applications of the Amplicor HBV Monitor test, a quantitative HBV DNA PCR assay. J Virol Methods 1998;74:155-165.

[24] Ranki M, Schatzl HM, Zachoval R, Uusi-Oukari M, Lehtovaara P. Quantitation of hepatitis B virus DNA over a wide range from serum for studying viral replicative activity in response to treatment and in recurrent infection. Hepatology 1995;21:1492-1499.

[25] Centers for Disease Control and Prevention, Report of the NIH panel to define principles of therapy of HIV infection and guidelines for the use of antiretroviral agents in HIV-infected adults and adolescents. Morb Mortal Wkly Rep 1998;47(RR5):1-41.

[26] Centers for Disease Control, 1993 Revised classification system for HIV infection and expanded surveillance case definition for AIDS among adolescents and adults. Morb Mortal Wkly Rep 1992; 41(RR17):1-19.

[27] Lewin SR, Ribeiro RM, Walters T, Lau GK, Bowden S, Locarnini S, Perelson AS. Analysis of hepatitis B viral load decline under potent therapy: complex decay profiles observed. Hepatology 2001;34: 1012-1020.

[28] Pichoud C, Berby F, Stuyver L, Petit MA, Trepo C, Zoulim F. Persistence of viral replication after anti-HBe seroconversion during antiviral therapy for chronic hepatitis B. J Hepatol 2000;32:307-316.

[29] Carr A, Cooper DA. Restoration of immunity to chronic hepatitis B infection in HIV-infected patient on protease inhibitor. Lancet 1997; 349:995-996.

[30] Velasco M, Moran A, Tellez JM. Resolution of chronic hepatitis B after ritonavir treatment in an HIV-infected patient. N Engl J Med 1999;340:1765-1766.
[31] Benhamou Y, Bochet M, Thibault V, Di Martino V, Caumes E, Bricaire F, et al. Long-term incidence of hepatitis B virus resistance to lamivudine in human immunodeficiency virus-infected patients. Hepatology 1999;30:1302-1306.

[32] Tsiang M, Rooney JF, Toole JJ, Gibbs CS. Biphasic clearance kinetics of hepatitis B virus from patients during adefovir dipivoxil therapy. Hepatology 1999;29:1863-1869.

[33] Perelson AS, Essunger P, Cao Y, Vesanen M, Hurley A, Saksela K, et al. Decay characteristics of HIV-1-infected compartments during combination therapy. Nature 1997;387:188-191.

[34] Hsia CC, Thorgeirsson SS, Tabor E. Expression of hepatitis B surface antigen and core antigens and transforming growth factor-alpha in 'oval cells' of the liver in patients with hepatocellular carcinoma. J Med Virol 1994;43:216-221.

[35] Lowes KN, Brennan BA, Yeoh GC, Olynyk JK. Oval cell numbers in human chronic liver diseases are directly related to disease severity. Am J Pathol 1999;154:537-541.

[36] Workgroup for the elaboration of recommendations on viral hepatitis in HIV-infected patients. Coinfection by HIV and hepatitis A, B and C virus in adult patients: Review and GESIDA/PNS recommendations, 2003. Available from URL: http://www.hivandhepatitis.com/pdf/ HIVandhepatitiscom.pdf

[37] Pillay D, Cane PA, Ratcliffe D, Atkins M, Cooper D. CAESAR coordinating committee. Evolution of lamivudine-resistant hepatitis B virus and HIV-1 in co-infected individuals: an analysis of the CAESAR study. AIDS 2000;14:1111-1116.

[38] Wolters LM, Niesters HG, Hansen BE, van der Ende ME, Kroon FP, Richter C, et al. Development of hepatitis B virus resistance for lamivudine in chronic hepatitis B patients co-infected with the human immunodeficiency virus in a Dutch cohort. J Clin Virol 2002;24: $173-181$

[39] Benhamou Y, Bochet M, Thibault V, Calvez V, Fievet MH, Sullivan $\mathrm{M}$, et al. Adefovir dipivoxil $10 \mathrm{mg}$ suppresses $\mathrm{HBV}$ viral replication in HIV/HBV coinfected patients with lamivudine resistant HBV. Program \& Abstracts: 9th CROI, Seattle; 2002. p. a123. abstract.

[40] Chen DS, Hoyer BH, Nelson J, Purcell RH, Gerin JL. Detection and properties of hepatitis viral DNA in liver tissue from patients with hepatocellular carcinoma. Hepatology 1982;2:42S-46S. 